\title{
Analisis Pengembangan Badan Usaha Milik Desa (BUMDes) Harapan Oesena Di Desa Oesena Kecamatan Amarasi Kabupaten Kupang
}

\author{
Ade Onny Siagan \\ Universitas Bina Sarana Informatika, Jakarta \\ ade.aoy@bsi.ac.id
}

\begin{abstract}
This research aims to analyze the economic potential in Oesena village, analyze the management progress of Oesena village, analyze the strength, the weakness, the opportunity, and the threat in developing the BUMDes of Oesena village. This research was the type of case study research that used descriptive qualitative approach. This research used the way of analysing the strategy and the meaning qualitatively. In deciding the informants for this research, the purposive sampling technique where the decision of the informants was done consciously according to some criteria and the informants were people who could give the informations about BUMDes in Oesena village to the researcher. There were two techniques for analysing the data such as the technique of data analysis and the technique of SWOT analysis. The research results showed that the development of BUMDes in Oesena Village was still unstable. It could be seen from lack of support for the economic potentials in this village, lack of participation or the follow-up from the BUMDes manager and also the villagers; The progress level of this village was still low and there was no significant increase; the strengths could be seen from the potentials of natural resources, weavings, and the villagers'soft skills, the weakness could be seen from the limited potential of human resources, the lack of understanding and initiative of the villagers.
\end{abstract}

Keywords: Development, The Village-owned Business Entity, SWOT

Corresponding author:

Email Address : ade.aoy@bsi.ac.id (Jakarta, Jawa Timur)

Received 23 Januari 2021, Accepted 9 Pebruari 2021, Published 22 Pebruari 2021

\section{PENDAHULUAN}

Pada hakikatnya, desa merupakan entitas yang membentuk Negara Kesatuan Republik Indonesia (NKRI). Desa adalah adat yang merupakan unit pemerintah yang dikelola oleh masyarakat adat dan mempunyai hak untuk mengurus wilayah dan kehidupan masyarakat dalam lingkungan desa adat. Menurut pasal 1 dan point 1 Undang-Undang Nomor 6 Tahun 2014 tentang desa adalah persatuan masyarakat hukum yang memiliki batas wilayah yang berwenang untuk mengatur dan mengurus urusan pemerintah kepada masyarakat setempat berdasarkan prakarsa masyarakat, hak asal usul, atau hak yang diakui dan dihormati dalam sistem pemerintah Negara Kesatuan Republik Indonesia. (RPJM-DESA Oesena Kecamatan Amarasi Kabupaten Kupang, 2017-2022). Cara desa dalam menjaga aset ekonomi ini berbalikan dengan model pemerintah yang bersifat ekstraktif karena menyerahkan pengelolaan alam itu kepada sektor swasta daripada mengutamakan stakeholder tingkat masyarakat lokal. Sementara lingkungan kelembagaan ekonomi desa yang lebih inklusif malah tidak menjadi referensi dari model pengembangan ekonomi lokal. (Wijaya, 2018).

Pengembangan basis ekonomi perdesaan dijalankan pemerintah melalui berbagai program yakni pengembangan Produk Unggulan Kawasan Perdesaan (Prukades), membangun embung air desa, mengembangkan Badan Usaha Milik Desa, dan membangun sarana Olahraga Desa (Raga Desa). Tapi usaha tersebut belum membuahkan hasil memuaskan seperti yang diinginkan bersama. Banyak faktor yang menyebabkan kurang berhasilnya berbagai program itu, salah satu faktor yang paling dominan adalah intervensi pemerintah terlalu besar (Kurniasih et al., 2019). Akibatnya ialah menghambat daya kreativitas dan inovasi masyarakat desa dalam mengelola dan menjalankan mesin ekonomi di perdesaan. Sistem dan kelembagaan ekonomi pada 
perdesaan tidak berjalan efektif serta berimplikasi terhadap ketergantungan akan bantuan pemerintah sehingga mematikan semangat kemandirian. (Siagian, 2020).

BUM Desa tidak lagi didirikan menurut instruksi pemerintah, namun keinginan masyarakat desa, mulai dari pengelolaan potensi akan menimbulkan permintaan pasar. Agar keberadaan lembaga ekonomi ini tidak dikuasai oleh kelompok tertentu yang memiliki modal besar di perdesaan, maka kepemilikan lembaga itu oleh desa dikontrol bersama di mana tujuan utamanya meningkatkan standar hidup ekonomi masyarakat. (Siagian, 2019). Pendirian lembaga itu bertujuan mengurangi peran tengkulak yang menyebabkan biaya transaksi naik antara harga produk produsen perdesaan menikmati selisih harga jual produk dan biaya produk yang layak dan konsumen tidak menanggung harga pembelian yang mahal.

Lembaga itu bertujuan membantu kebutuhan dana masyarakat bersifat konsumtif dan produktif, menjadi distributor utama untuk memenuhi kebutuhan sembilan bahan pokok (sembako) dan menumbuh kembangkan kegiatan pelaku ekonomi di perdesaan.(Siagian et al., 2020). Bentuk kelembagaan seperti disebutkan diatas dinamakan BUMDes. BUMDes sesungguhnya telah diamanatkan pada Undang-Undang Nomor 32 Tahun 2004 tentang pemerintahan daerah (bahkan oleh UndangUndang Nomor 22 Tahun 1999) dan peraturan Pemerintah Nomor 72 Tahun 2005 tentang desa. Pendirian BUMDes harus disertai upaya penguatan kapasitas dan didukung oleh kebijakan daerah (Kabupaten/kota) yang memfasilitasi serta melindungi usaha tersebut dari ancaman persaingan pemodal besar.

Mengingat BUMDes adalah lembaga ekonomi baru yang beroperasi di perdesaan dan memerlukan landasan yang kuat untuk tumbuh dan berkembang, maka pemerintah berperan membangun dasar pendirian BUMDes.(Siagian \& Prasetyo, 2020). Berdasarkan asumsi itulah maka sudah seharusnya eksistensi desa mendapatkan perhatian yang serius dari pemerintah pusat dengan lahirnya kebijakankebijakan terkait dengan pemberdayaan ekonomi yang dilakukan dengan cara menghimpun dan melembagakan kegiatan ekonomi. BUMDes lahir sebagai suatu pendekatan baru dalam usaha peningkatan ekonomi desa berdasarkan kebutuhan dan potensi desa.
Pengelolaan BUMDes sepenuhnya dilaksanakan oleh masyarakat desa, yaitu dari desa, oleh desa, dan untuk desa. (Zulkarnaen, 2016). Tiga usaha aktif dijalankan dan satu usaha masih dalam perencanaan dengan menyusun strategi. Unit usaha dagang aktif dengan penyediaan barang-barang kebutuhan masyarakat, unit usaha SPP dapat menolong kebutuhan masyarakat dalam kebutuhan maupun berwirausaha, unit usaha sewa dapat menolong masyarakat dalam memperlancar pekerjaan. Dan unit usaha pariwisata dalam perencanaannya yang akan dinikmati oleh wisatawan dan masyarakat. Mengingat Pendapatan Asli Desa (PAD) dengan program pemerintah yang harus terus diberi perhatian dan tinjak lanjut, pemerintah dan perangkat desa berupaya bekerja sama dalam mengelola dan mendukung lembaga pengembangan ini dengan baik. Kebijakan pemerintah mengenai BUMDes tersebut telah mendorong banyak pemerintah daerah untuk melakukan studi banding ke daerah-daerah yang telah menjalankan BUMDes. (Budiono, 2015).

Berdasarkan hasil observasi pengembangan BUMDes yang belum berjalan dengan semestinya karena diduga yaitu belum meratanya inisiatif dari masyarakat dalam pengembangan BUMDes, perangkat desa, pengelola BUMDes dan masyarakat belum maksimal dalam mengelola potensi-potensi dalam pengembangan BUMDes, belum meratanya pelatihan-pelatihan dan sosialisasi bagi perangkat desa, pengelola BUMDes, dan masyarakat, kualitas kinerja pengelola BUMDes masih rendah, keadaan BUMDes belum dijangkau dengan baik, pendistribusian usaha menggunakan gedung polindes, masyarakat menilai BUMDes masih baru dan belum efektif. Maka peneliti akan melakukan penelitian dalam memperhatikan potensi-potensi ekonomi desa, tingkat kemajuan pengelolaan BUMDes; kekuatan, kelemahan, peluang dan ancaman dalam pengembangan BUMDes; dan strategi pengembangan BUMDes yang diterapkan di desa Oesena.

\section{METODE PENELITIAN}

Jenis penelitian dalam penelitian ini adalah studi kasus Pemilihan lokasi sesuai dengan data masalah yang didapatkan yang berlokasi di desa Oesena, Kecamatan Amarasi, Kabupaten Kupang. Waktu periodisasi data yang dibutuhkan selama 2 bulan. Pendekatan Penelitian yang digunakan adalah penelitian 
deskriptif kualitatif. Data yang digunakan dalam penelitian ini adalah Data primer dan data Sekunder.

\section{Teknik Pengumpulan Data}

Dalam mengumpulkan data dan informasi digunakan beberapa teknik, Observasi Wawancara, Dokumentasi, Adapun kriteria dari informan yang ditunjuk atau dipilih dalam penelitian ini adalah: (1) Kepala desa dan aparatur desa, (2) Pengelola BUMDes harapan oesena. (3) Masyarakat desa oesena Untuk menyajikan data agar mudah dipahami, maka langkah-langkah analisis data yang digunakan dalam penelitian ini adalah Analysis Interactive Model dari (Miles \& Huberman, 2012), yang membagi langkah-langkah dalam kegiatan analisis data dengan beberapa bagian yaitu pengumpulan data (data collection), reduksi data (data reduction), penyajian data (data display), dan penarikan kesimpulan atau verifikasi (conclutions).

\section{HASIL PENELITIAN DAN PEMBAHASAN}

Desa Oesena memiliki luas wilayah lebih kurang $1800 \mathrm{Km} 2$ yang termasuk dalam wilayah kecamatan Amarasi, Kabupaten Kupang. Desa Oesena berbukit-bukit dengan dataran terbesar secara sporadis pada gugusan yang sempit diapit dataran tinggi atau perbukitan. Lahan dengan kemiringan 15-40 persen mencapai lulusan $38,07 \%$ dan lahan dengan kemiringan lebih dari $40 \%$ mencapai $35,46 \%$. Kondisi geomorfologis yang demikian menyebabkan pertanian pada dataran sangat terbatas pada pertanian lahan kering.

Pertanian lahan kering banyak dilakukan pada daerah- daerah dengan kemiringan yang curam sehingga produktivitas menjadi rendah.

Gambar 4.1 Peta Desa Oesena

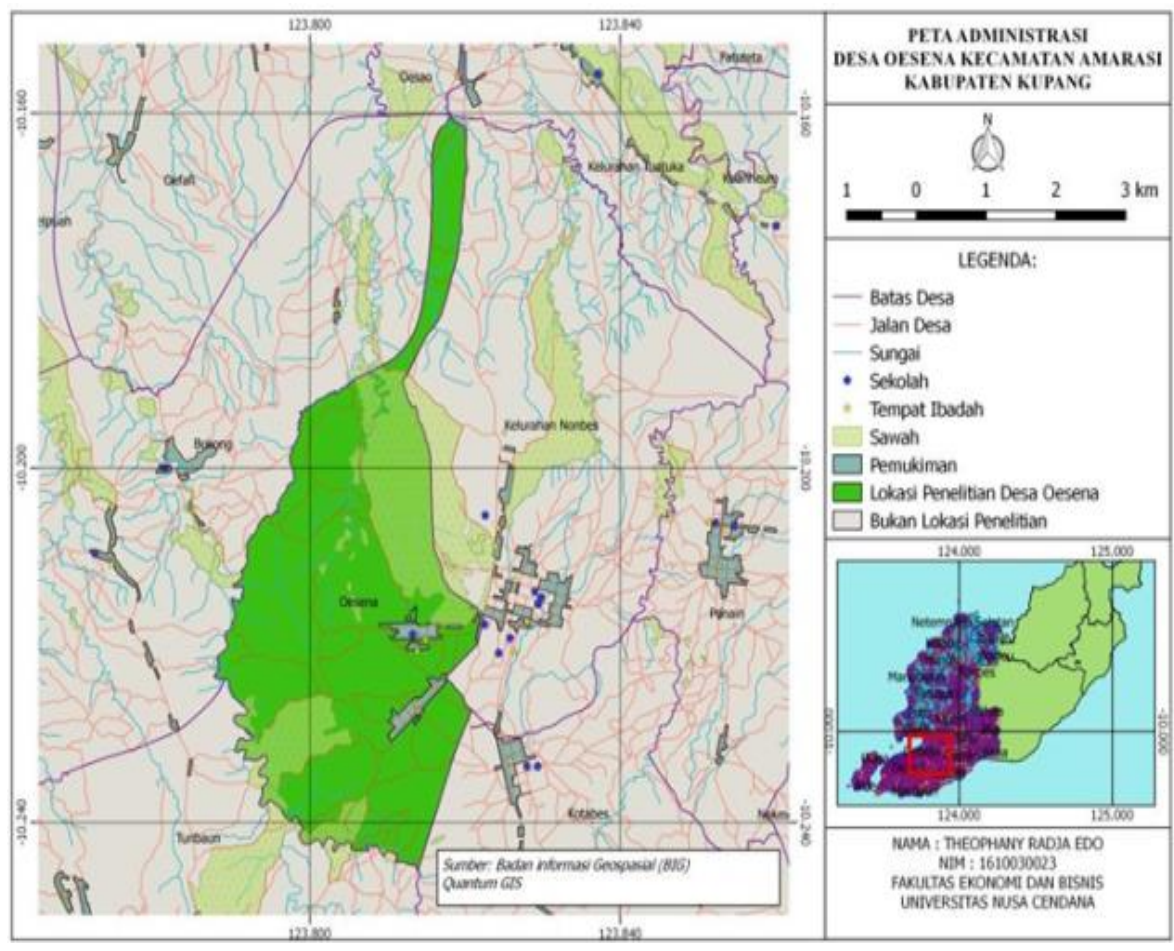

a. Kependudukan

Kondisi desa Oesena berdasarkan struktur keluarga penduduk dan rata-rata anggota keluarga sebagai berikut, desa Oesena memiliki jumlah keluarga sebanyak $380 \mathrm{KK}$, jumlah penduduk sebanyak 1.497 jiwa dengan rata-rata anggota keluarga sebanyak 4 jiwa. Penduduk desa Oesena sebanyak 1.497 jiwa yang terdiri dari laki-laki 736 jiwa dan 761 jiwa perempuan. Masyarakat desa Oesena umumnya memeluk agama kristen protestan sebanyak $98 \%$ sisanya adalah Kristen, Katolik dan Islam.

b. Tingkat Pendidikan

Berdasarkan tingkat pendidikan penduduk Oesena Kecamatan Amarasi Kabupaten Kupang dapat dilihat tingkat pendidikan 
terbanyak ialah SMP dengan total persentase $38 \%$ jika ditambah dengan total SMA maka jumlah persentase $69 \%$. Desa Oesena dengan jumlah penduduk 1.497 jiwa dengan latar belakang pendidikan sebagai berikut:

Tabel 4.1

Tingkat Pendidikan

\begin{tabular}{|l|c|c|}
\hline Tingkat Pendidikan & Jumlah Jiwa & Persentase (\%) \\
\hline Tidak/belum sekolah & 4 & 0,3 \\
\hline TK & 29 & 1,4 \\
\hline SD & 375 & 25 \\
\hline SMP & 564 & 38 \\
\hline SMA & 459 & 31 \\
\hline Perguruan Tinggi & 66 & 4,4 \\
\hline Total & 1.497 & 100 \\
\hline
\end{tabular}

Sumber : Data Desa Oesena, 2019

c. Mata Pencaharian

Desa Oesena dengan jumlah penduduk 1.497 jiwa dengan latar belakang mata pencaharian sebagai berikut :

Tabel 4.2

Mata Pencaharian

\begin{tabular}{|l|c|c|}
\hline $\begin{array}{l}\text { Jenis Mata } \\
\text { Pencaharian }\end{array}$ & Jumlah Jiwa & $\begin{array}{c}\text { Persentasi } \\
(\mathbf{\%})\end{array}$ \\
\hline TNI-Polri & 1 & 0,06 \\
\hline PNS & 12 & 0,8 \\
\hline Pegawai Swasta & 21 & 1,4 \\
\hline Pensiunan & 7 & 0,4 \\
\hline Petani & 1.070 & 71,5 \\
\hline Buruh & 7 & 0,4 \\
\hline $\begin{array}{l}\text { Belum/sedang } \\
\text { cari kerja }\end{array}$ & 379 & 25 \\
\hline Total & 1.497 & 100 \\
\hline
\end{tabular}

Sumber : Data Desa Oesena, 2019

Berdasarkan mata pencaharian penduduk Oesena Kecamatan Amarasi Kabupaten Kupang maka jenis mata pencaharian terbanyak ialah petani dengan total persentase $71,5 \%$.

\section{Deskripsi Potensi-Potensi Ekonomi di Desa Oesena}

Potensi ekonomi adalah aset atau kekuatan desa yang perlu disadari serta diperhatikan dan dikembangkan untuk kemajuan desa. Peneliti akan memaparkan hasil penelitian mengenai potensi-potensi di desa Oesena seperti potensi sumber daya alam, potensi sumber daya manusia, potensi kelembagaan, potensi prasarana dan sarana, dan potensi tenun ikat.

\section{Potensi Sumber Daya Alam}

Berikut ini adalah potensi sumber daya alam dengan luas wilayah pegunungan, tanah sawah dan tanah kering. Penjelasannya sebagai berikut. Desa Oesena memiliki jenis dan kesuburan tanah yang bermacam- macam seperti sebagian besar warna tanah coklat merah dengan tekstur tanah yang padat berpasir. Dengan jenis dan kesuburan tanah tersebut juga dapat dilihat dengan luas wilayah pegunungan yang telah dipaparkan tersebut dengan total wilayah pegunungan, tanah basah dan tanah kering sluas 3.155,14 ha.

Tabel 4.3

Potensi Ekonomi SDA

\begin{tabular}{|l|c|c|}
\hline Potensi Ekonomi SDA & Luas $(\mathrm{Ha})$ & Persentase $(\%)$ \\
\hline Luas Wilayah Pegunungan & & 5,16 \\
\hline Luas Persawahan & 160 & 2,76 \\
\hline Luas Perkebunan & 87,19 & 47,76 \\
\hline Luas Prasarana umum & 1.507 & 0,29 \\
\hline Sawah irigasi 1/2 teknis & 9,3 & 2,79 \\
\hline Tegal/ladang & $1.267,7$ & 40,17 \\
\hline Tanah basah & 2 & 0,06 \\
\hline Tanah perkebunan & 34,05 & 1,16 \\
\hline Total & $3.155,14$ & 100 \\
\hline
\end{tabular}

Sumber : Data Desa Oesena, 2019.

Berdasarkan potensi ekonomi luas wilayah pegunungan yang menjadi keunggulan adalah potensi luas perkebunan $47,76 \%$ dan potensi tegal/lading $40,17 \%$. Dengan potensi tersebut pemanfaatannya digunakan untuk menanam jenis tanaman, dan buah-buahan di desa Oesena Kecamatan Amarasi Kabupaten Kupang. Menurut jenis tanaman desa Oesena Kecamatan Amarasi Kabupaten Kupang, jenis tanaman dengan penghasilan terbanyak adalah jenis tanaman padi lading dengan persentase $52,8 \%$ dan jagung dengan persentase $44,2 \%$.

Pemanfaatan keunggulan jenis tanaman untuk memenuhi kebutuhan masyarakat seharihari dan juga yang dijual dalam pemenuhan kebutuhan hidup. Berdasarkan jenis buahbuahan desa Oesena Kecamatan Amarasi Kabupaten Kupang, jenis buah-buahan dengan penghasilan terbanyak adalah kemiri dengan persentase $71,2 \%$ dan pisang dengan persentase $7,1 \%$. Pemanfaatan keunggulan jenis buahbuahan untuk memenuhi kebutuhan sehari-hari dan dijual untuk pemenuhan hidup masyarakat.

Berdasarkan jenis ternak desa Oesena Kecamatan Amarasi Kabupaten Kupang, jenis 
ternak dengan penghasilan jumlah populasi terbanyak adalah ayam kampung dengan $29,81 \%$

Tabel 4.4

Jenis Tanaman Desa Oesena

\begin{tabular}{|l|c|c|c|}
\hline $\begin{array}{l}\text { Jenis } \\
\text { tanaman }\end{array}$ & $\begin{array}{l}\text { Luas } \\
(\mathbf{H a})\end{array}$ & $\begin{array}{c}\text { Satuan } \\
(\mathbf{K g})\end{array}$ & $\begin{array}{c}\text { Persentase } \\
(\mathbf{\%})\end{array}$ \\
\hline Bayam & 10 & 200 & 0,29 \\
\hline Kangkung & 10 & 150 & 0,21 \\
\hline Kacang Turis & 10 & 300 & 0,43 \\
\hline Umbi-umbian & 12 & 150 & 0,21 \\
\hline Total & 120 & 69.832 & 100 \\
\hline Jagung & 12 & 30.875 & 44,2 \\
\hline Kacang tanah & 3 & 500 & 0,72 \\
\hline $\begin{array}{l}\text { Kacang } \\
\text { panjang }\end{array}$ & 14 & 112 & 0,16 \\
\hline Kacang hijau & 3 & 200 & 0,29 \\
\hline Padi ladang & 12 & 36.875 & 52,8 \\
\hline Ubi kayu & 12 & 150 & 0,21 \\
\hline Ubi jalar & 10 & 120 & 0,17 \\
\hline Cabe & 10 & 120 & 0,17 \\
\hline Terong & 2 & 200 & 0,29 \\
\hline
\end{tabular}

Sumber : Data desa Oesena, 2019.

Tabel 4.5

Jenis Buah - Buahan desa Oesena

\begin{tabular}{|l|c|c|c|}
\hline $\begin{array}{l}\text { Jenis buah- } \\
\text { buahan }\end{array}$ & $\begin{array}{c}\text { Jumlah } \\
\text { pohon }\end{array}$ & $\begin{array}{c}\text { Satuan } \\
(\mathbf{K g})\end{array}$ & $\begin{array}{c}\text { Persentase } \\
(\mathbf{\%})\end{array}$ \\
\hline Jeruk & 50 & 300 & 4,3 \\
\hline Alpokad & 25 & 20 & 0,28 \\
\hline Mangga & 197 & 300 & 4,3 \\
\hline Pepaya & 260 & 400 & 5,7 \\
\hline Belimbing & 90 & 150 & 2,1 \\
\hline Pisang & 300 & 500 & 7,1 \\
\hline Kemiri & 700 & 5000 & 71,2 \\
\hline Jeruk nipis & 60 & 115 & 1,64 \\
\hline Jambu air & 60 & 200 & 2,85 \\
\hline Nangka & 260 & 20 & 0,35 \\
\hline Sirsak & 260 & 10 & 0,14 \\
\hline Nenas & 13 & 6 & 0,12 \\
\hline Total & 2.275 & 7.021 & 100 \\
\hline
\end{tabular}

Sumber : Data Desa Oesena, 2019.

Tabel 4.6

Jenis Ternak Desa Oesena

\begin{tabular}{|l|c|c|l|}
\hline $\begin{array}{l}\text { Jenis } \\
\text { Ternak }\end{array}$ & Peternak & $\begin{array}{c}\text { Jumlah Populasi } \\
\text { (ekor) }\end{array}$ & $\begin{array}{c}\text { Persentase } \\
(\%)\end{array}$ \\
\hline Sapi & 230 & 500 & 24,04 \\
\hline Babi & 307 & 410 & 19,71 \\
\hline $\begin{array}{l}\text { Ayam } \\
\text { Kampung }\end{array}$ & 230 & 620 & 29,81 \\
\hline Kambing & 100 & 210 & 10,12 \\
\hline Anjing & 150 & 250 & 12 \\
\hline Kucing & 50 & 90 & 4,33 \\
\hline Total & 1.067 & 2.080 & 100 \\
\hline
\end{tabular}

Sumber : Data Desa Oesena, 2019 dan sapi $24,04 \%$. Pemanfaatan keunggulan jenis ternak untuk memenuhi kebutuhan sehari- hari dan dijual untuk pemenuhan hidup masyarakat.

Potensi-potensi lainnya juga ada seperti potensi kehutanan dengan hasil hutan seperti bambu sebanyak 1.316 rumpun, jati sebanyak 17.000, mahoni sebanyak 8000 pohon, cemara sebanyak 12000 pohon, dan kayu cendana sebanyak 20 pohon. Desa Oesena memiliki potensi sumber daya air seperti adanya mata air dengan debit 12 M3/Dtk dan sumur gali bervolume 15 M3. Pemanfaatan potensi kehutanan dengan hasil hutan seperti bamboo, jati dan mahoni juga dimanfaatkan untuk memenuhi kebutuhan sehari-hari dan dijual untuk pemenuhan hidup masyarakat.

Demikian potensi alam ini adalah kekayaan alam yang terdapat di bumi yang dapat dimanfaatkan untuk memenuhi kebutuhan hidup manusia pada umumnya, perkembangannya masih butuh secara cermat oleh sumber daya manusia. Sesuai rumusan masalah pada bab 1 mengenai kekuatan potensi- potensi ekonomi seperti sumber daya alam. Berdasarkan hasil wawancara informan Bapak Nelson Boymau sebagai Kepala Desa Oesena pada tanggal 04 Februari 2020 : "potensi-potensi alam di desa Oesena melimpah seperti kekayaan alam, ternak dan hasil alam lainnya, namun masyarakat masih mengelola secara sendiri-sendiri untuk memenuhi kebutuhan sehari-hari, masyarakat belum melihat pentingnyas BUMDes, sehingga mereka juga belum mau untuk memberikan usaha-usaha atau hasil alam untuk dikelola oleh BUMDes".

Pemanfaatan Sumber Daya Alam penduduk Oesena belum efektif selain digunakan untuk kebutuhan sehari-hari dan dijual untuk kebutuhan, seharusnya penduduk Oesena harus mampu memanfaatkan SDA untuk peningkatan layanan serta dukungan bagi usaha masyarakat, sehingga dalam pemanfaatan SDA yang dimiliki, masyarakat desa mampu memperkuat kelembagaan produksi sambil memaknai keterlibatannya pada siklus tata pemerintahan desa serta dalam upaya untuk pengembangan BUMDes.

Jika dilihat potensi-potensi desa sangat penting untuk diperhatikan lagi serta didukung dengan adanya inisiatif masyarakat desa yang 
mau mendukung dan mengapresiasi BUMDes untuk mengelola hasil alam di desa Oesena.

\section{Potensi Sumber Daya Manusia}

Sumber daya manusia adalah salah satu komponen penting dalam sebuah organisasi. Berikut ini adalah kualitas angkatan kerja yang ada di desa Oesena.

\section{Tabel 4.7}

Kualitas Angkatan Kerja Penduduk Oesena

\begin{tabular}{|l|c|c|c|c|}
\hline Angkatan kerja & L & P & Jumlah & \% \\
\hline $\begin{array}{l}\text { Penduduk usia 18-56 tahun yang } \\
\text { buta aksara dan huruf/angka latin }\end{array}$ & 20 & 33 & 53 & 9,28 \\
\hline $\begin{array}{l}\text { Penduduk usia 18-56 tahun yang } \\
\text { tidak tamat SD }\end{array}$ & 4 & 6 & 10 & 1,75 \\
\hline $\begin{array}{l}\text { Penduduk usia 18-56 tahun yang } \\
\text { tamat SD }\end{array}$ & 129 & 187 & 316 & 55,34 \\
\hline $\begin{array}{l}\text { Penduduk usia 18-56 tahun yang } \\
\text { tamat SLTP }\end{array}$ & 42 & 48 & 90 & 15,76 \\
\hline $\begin{array}{l}\text { Penduduk usia 18-56 tahun yang } \\
\text { tamat SLTA }\end{array}$ & 48 & 34 & 82 & 14,36 \\
\hline $\begin{array}{l}\text { Penduduk usia 18-56 tahun yang } \\
\text { tamat perguruan tinggi }\end{array}$ & 8 & 12 & 20 & 3,50 \\
\hline Jumlah & 251 & 320 & 571 & 100 \\
\hline
\end{tabular}

Sumber : Data Desa Oesena, 2019.

Berdasarkan kualitas angkatan kerja penduduk Oesena Kecamatan Amarasi Kabupaten Kupang, angkatan kerja dengan persentase yang tertinggi adalah angkatan kerja penduduk usia 18-56 tahun yang tamat SD dengan persentase $55,34 \%$. Dengan persentase tertinggi adalah tamatan SD masyarakat tersebut beralih ke buruh tani dan menetap di desa untuk bekerja dalam memenuhi kebutuhan sehar-hari.

Berdasarkan hasil wawancara informan Bapak Nelson Boymau sebagai Kepala Desa Oesena pada tanggal 04 Februari 2020 : "SDM di desa Oesena belum maksimal, dapat dilihat dari kinerja yang belum profesional, sehingga membutuhkan pelatihan dan sosialisasi serta kesadaran dan tindak lanjut dari masyarakat, sehingga kualitas SDM lebih baik apalagi dalam mengembangkan BUMDes". Sumber daya manusia dinilai sangat penting dan menjadi kunci dalam menentukan perkembangan BUMDes serta memajukan desa secara mandiri dan sejahtera serta menghasilkan pendapatan asli daerah yang maksimal.

\section{Potensi Kelembagaan}

Pada potensi kelembagaan, pemerintah desa Oesena memiliki dasar hukum yang membentuk lembaga desa dengan jumlah perangkat desa sebanyak 9 unit kerja, antara lain : kepala desa, sekertaris desa, kepala seksi pemerintahan, kepala seksi pembangunan dan ekonomi, kepala seksi kesejahteraan sosial, kepala urusan tata usaha dan umum, kepala urusan keuangan dan kepala urusan pendataan. Desa Oesena juga memiliki tiga (3) dusun yang aktif yaitu dusun 1 Huko'u, dusun 2 Oenepu, dusun 3 Oeboen. Tingkat pendidikan aparat/lembaga desa juga rata-rata memiliki pendidikan terakhir SMA dan hanya staf saja yang memiliki pendidikan terakhir sarjana. Badan Permusyawaratan Desa memiliki 9 orang anggota dengan rata-rata latar belakang pendidikan anggota BPD adalah SMA.

Lembaga kemasyarakatan desa juga dibentuk dengan dasar hukum pembentukan sesuai SK Kepala Desa dengan jumlah pengurus sebanyak 13 orang. PKK desa Oesena dibentuk dari dasar hukum pembentukan sesuai keputusan desa dengan jumlah pengurus sebanyak 7 orang dengan ruang lingkup kegiatan sebagai berikut : ketua, sekertaris, bendahara, pokja I, pokja II, pokja II, pokja III, pokja IV. Desa Oesena memiliki karang taruna dengan dasar hukum pembentukan sesuai SK Kepala Desa, dengan jumlah pengurus sebanyak 12 orang serta adanya juga ruang lingkup kegiatan kelompok tani dan lembaga adat. Desa Oesena memiliki lembaga BUMDes sesuai dasar hukum pembentukan dengan ketentuan UU No. 6 tahun 2014 pasal 87 tentang pendirian, pengelolaan, dan menjalankan usaha dengan ketentuan praturan undang-undang.

Ada juga organisasi keagamaan dengan organisasi tiga (3) lingkungan dengan dasar hukum pembentukan sesuai SK kepala desa dengan jumlah pengurus sebanyak 17 orang. Lembaga ekonomi desa Oesena sebagai berikut, pertama lembaga ekonomi dan unit usaha desa berupa kelompok simpan pinjam, dengan jumlah kelompok 4 unit, jumlah kegiatan 2 dan jumlah pengurus dan anggota sebanyak 75 orang. Kedua usaha jasa pengangkutan berupa angkutan antar kota/provinsi dengan unit yang belum diketahui dengan jelas. Ketiga usaha jasa keterampilan berupa tukang kayu dengan jumlah tukang 40 orang, tukang batu dengan jumlah tukang 102 orang, dan tukang jahit/ border dengan jumlah penjahit delapan orang. 
Berdasarkan hasil wawancara informan Bapak Nelson Boymau sebagai Kepala Desa Oesena pada tanggal 04 Februari 2020 : "Bumdes sudah menjadi program pemerintah. Program tersebut masih belum maksimal dan akan terus di upayakan dalam memaksimalisasi pengembangan BUMDes, kendala saat ini tidak ada tindak lanjut dari pemerintah dan masyarakat, sehingga perlu adanya pendampingan dari lembaga yang berwenang dalam pengawasan aset yang harus dikelola dengan baik, karena kalau hasil pengelolaan bagus maka hasilnya juga pasti besar"

Bentuk kelembagaan seperti disebutkan diatas dinamakan Badan Usaha Milik Desa (BUMDes). Badan Usaha Milik Desa sesungguhnya telah diamanatkan pada undangundang No. 32 tahun 2004 tentang pemerintahan daerah (bahkan oleh unhdang-undang No. 22 tahun 1999) dan peraturan pemerintah No. 72 tahun 2005 tentang desa. Pendirian BUMDes harus disertai upaya penguatan kapasitas dan didukung oleh kebijakan daerahn (Kabupaten/kota) yang memfasilitasi serta melindungi usaha tersebut dari ancaman persaingann pemodal besar.

\section{Potensi Prasarana dan Sarana}

Sarana dan prasarana merupakan dua hal yang penting menunjang antara yang satu dengan yang satunya lagi. Namun bukan berarti jika tidak ada salah satu, maka salah satunya lagi tidak berfungsi sama sekali. Sarana berhubungan langsung dan menjadi penunjang utama dalam suatu aktivitas. Sedangkan prsarana adalah segala sesuatu yang menunjang secara langsung atau tidak langsung segala jenis sarana.

Berikut ini adalah potensi prasarana dan sarana di desa Oesena, sebagai berikut. Ada empat (4) jenis prasarana dan sarana yaitu : pertama, jalan desa, jalan antar desa/kelurahan/kecamatan, jalan kabupaten yang melewati desa, dan jembatan desa. Kualitas baik jalan desa dan jalan antar desa/ kelurahan/ kecamatan seperti panjang jalan aspal dan panjang jalan makadam. Dan kualitas jalan rusak sebagian jalan desa dan jalan antar/ kelurahan/ kecamatan seperti panjang jalan tanah.

Berdasarkan hasil wawancara informan Bapak Nelson Boymau sebagai Kepala Desa Oesena pada tanggal 04 Februari 2020 : "kekurangan yaitu, masyarakat tidak merata menjangkau BUMDes sehingga kurang bagus karena bumdes bukan dijalur kabupaten atau provinsi jadi kurang dijangkau dengan baik". Pendekatan yang diharapkan mendorong dan mengerakkan roda perekonomian perdesaan ialah pendirian prasarana dan sarana yang baik sehingga tujuannya agar masyarakat bisa mengalami kesejahteraan dalam mengembangkan BUMDes dengan baik.

\section{Potensi Tenun Ikat}

Desa Oesena memiliki potensi tenun ikat yang cukup baik dalam hal ini peneliti akan menjelaskan mengenai potensi tenun ikat yang dikelola dalam satu (1) kelompok dengan jumlah dari setiap masing-masing dusun yang bernama tenun ikat ainanfen (mama bangkit). Berdasarkan hasil wawancara informan Ibu Isri G. Menir sebagai pengelola tenun ikat dan masyarakat Desa Oesena pada tangga 28 April 2020: "tenun ikat asli Oesena memiliki dua jenis warna yaitu alam dan kimia, dalam pembuatan kain tenun, masyarakat cenderung memakai pewarna alami dan jarang jarang memakai yang kimia karena warnanya akan cepat luntur, obatnya mahal, dan sesuai juga dengan permintaan pesananan. Tenun ikat harganya bervariasi tergantung jenis tenun ikat yang dibuat. Pendistribusian tenun ikat disalurkan sesuai kebutuhan masyarakat. Masyarakat belum memberikan hasil tenun ikat ke BUMDes karena penilaian masyarakat terhadap BUMDes masih baru dan rendah".

Demikian disampaikan oleh ibu Mehelina Masneno sebagai pengelola tenun ikat dan masyarakat Desa Oesena pada tangga 28 April 2020 : “ Distribusi penyaluran disesuaikan untuk pameran atau sesuai pesanan, selebihnya akan dibawa ke kelompok tenun perdusun untuk didistribusikan sesuai kebutuhan kelompok tenun tersebut. Harapan dengan BUMDes kedepannya harus update supaya setiap produk atau usaha-usaha yang dijual atau dititipkan bisa dijangkau dengan baik oleh masyarakat atau orang luar". Dapat disimpulkan bahwa tenun ikat di Oesena memiliki keunggulan seperti memiliki tenunan secara alami dan motifnya yang khas secara turun- temurun dan dapat dikelola dengan baik. Namun belum mendapat kepercayaan terhadap BUMDes sebagai tempat penyaluran hasil usaha.

\section{Deskripsi Tingkat Kemajuan Pengelolaan BUMDes Harapan Oesena Di Desa Oesena}

Menurut undang-undang Nomor 32 tahun 2004 tentang pemerintahan daerah, 
BUMDes bertujuan meningkatkan Pendapatan Asli Daerah (PAD). Setiap pemerintah desa dapat mendirikan BUMDes. BUMDes didirikan menurut prakarsa masyarakat sesuai potensi yang dapat dikembangkan menggunakan sumber daya lokal dan permintaan pasar (Chintary \& Lestari, 2016) dan .

Menurut hasil wawancara informan Bapak Nelson Boymau selaku Kepala Desa Oesena pada tanggal 04 Februari 2020 : "BUMDes merupakan program pemerintah, yang diwajibkan untuk setiap desa ada BUMDes dengan tujuannya sebagai roda perputaran uang di desa". Melihat arti pentingnya BUMDes bagi peningkatan kesejahteraan masyarakat. Melalui pemerintah desa, masyarakat harus dimotivasi, disadarkan dan dipersiapkan untuk membangun hidupnya. Persiapan yang dipandang belum begitu maksimal dan fokus pada sosialisasi, pendidikan serta pelatihan kepada pemangku kepentingan untuk peningkatan standar hidup masyarakat desa (pemerintah desa, BPD, ketua dusun, dan ketua lembaga BUMDes di perdesaan)(Kusuma, 2018).

Berdasarkan hasil wawancara informan Ibu Merry Ora sebagai Kepala Direksi BUMDes di Desa Oesena pada tanggal 04 Februari 2020 : "pembentukan BUMDes adalah program Jokowi, pemerintah pusat mengupayakan semua desadesa harus membuat BUMDes. Secara nasional sudah ada BUMN, sehingga di desa ada BUMDes. Makanya desa Oesena mendirikan BUMDes supaya mengcover penghasilan dari desa dan masyarakat untuk bisa dikelola oleh BUMDes".

Pendirian BUMDes tidaklah cukup mengungkit kebangkitan perekonomian desa sesuai cita - cita Indonesia. Peningkatan kesejahteraasn masyarakat desa dibangun melalui emoat pilar, yaitu: kekuatan kelembagaan dan modal usaha produksi kolektif masyarakat, keterlibatan bermakna masyarakat dalam tata pemerintahan desa, penguasaan literasi keuangan usah dan pengembangan serta pengelolaan BUMDes yang handal. Demikian juga berdasarkan hasil wawancara informan Ibu Merry Ora sebagai Direksi BUMDes di Desa Oesena pada tanggal 04 Februari 2020 :

"Respon masyarakat berbeda-beda, ada yang mendukung ada juga yang masih cuek saja, tapi prinsipnya biar yang tidak mendukung dia dibelakang karena mereka mungkin belum lihat dengan mata kepala bahwa BUMDes itu bisa berjalan seperti ini kalau memang, masyarakatnya bisa saling menopang bersama kami, karena itu lebih bagus. Makanya kalau saya diundang ketika rapat-rapat di desa, saya selalu bilang, kita sudah punya tempat untuk mempromosikan suatu barang jadi apapun hasil usaha kita bisa dijual atau dipromosikan di BUMDes, tapi itu masyarakat yang kurangt merespon".

\section{Deskripsi Kekuatan, Kelemahan, Peluang, dan Ancaman dalam pengembangan BUMDes}

Berdasarkan hasil penelitian bersama informan terpilih Bapak Kepala Desa Oesena, Direksi BUMDes, dan masyarakat secara analisis makro dan mikro akan dirumuskan variabel peluang dan ancaman. Sedangkan dari analisis internal akan dirumuskan variabel kekuatan dan kelemahan. Rumusan variabel yang peneliti dapat sebagai berikut.

\section{Kekuatan:}

1. Desa Oesena memiliki potensi sumber daya alam dan potensi tenun ikat yang baik.

2. Desa Oesena memiliki Badan Usaha Milik Desa yang sudah berlembaga undang-undang No. 32 tahun 2004 pasal 213.

3. Modal BUMDes 140.000 .000 dalam pengembangan empat unit usaha di desa Oesena, dengan PAD dari BUMDes tahun 2018 sebesar Rp. 6.463 .000

4. BUMDes Harapan Oesena memiliki empat unit usaha yang sedang berkembang, antara lain unit usaha dagang, unit usaha SPP, unit usaha sewa, unit usaha pariwisata.

5. Memberikan kemudahan untuk masyarakat memperoleh kebutuhan hidup berupa barang dan juga jasa.

\section{Kelemahan:}

1. Terbatasnya potensi SDM, potensi kelembagaan, dan potensi prasarana dan sarana.

2. Kurangnya pemahaman dan perencanaan dalam pengembangan BUMDes yang baik dan tepat dalam penganggaran dana desa yang telah diberikan.

3. Pengelola BUMDes belum bekerja atau menjalankan manajemen fungsional sesuai unit usaha dengan maksimal.

4. Kondisi BUMDes yang belum sepenuhnya dijangkau dengan baik oleh masyarakat.

5. Tidak adanya sosialisasi mengenai BUMDes bagi masyarakat sehingga kurangnya 
pemahaman, partisipasi dan inisiatif masyarakat dalam mendukung dan pengembangan BUMDes.

6. Adanya ketidakseimbangan hak dan kewajiban antara pengelola BUMDes dalam menjalankan program kerja.

7. Konsep pembangunan BUMDes yang selama ini dipahami masih sebatas pemahaman oleh sebagian perangkat desa dan atas arahan struktur BUMDes.

\section{Peluang:}

1. BUMDes adalah program pemerintah.

2. Anggaran dana desa dikeluarkan untuk pengembangan program-program desa.

3. Adanya peningkatan Pendapatan Asli Desa (PAD) jika adanya kerja sama antara perangkat desa, pengelola BUMDes dan masyarakat dengan baik.

4. BUMDes mempermudah masyarakat untuk memenuhi kebutuhan sehari- hari dan menghemat biaya transportasi

5. Mengisi kas daerah yang tujuannya untuk memajukan dan mengemangkan perekonomian daerah dan negera

6. Masyarakat dapat bekerja dan mendapatkan pendapatan tetap, sehingga dapat memenuhi kebutuhan rumah tangga atau memiliki tabungan untuk masa mendatang

\section{Ancaman:}

1. Belum terciptanya komunikasi yang baik antara pengelola desa dengan warga masyarakat mengenai berbagai program pengembangan BUMDes.

2. Adanya kerjasama dengan pihak ketiga seperti usaha swasta lainnya yang dapat mengancam perkembangan BUMDes.

3. Adanya persaingan dari badan usaha seperti Koperasi, Bank, atau usaha- usaha sejenisnya.

4. Jika adanya anggota-anggota BUMDes yang menjadi anggota koperasi

5. Penilaian yang keliru seperti urangnya inisitif dari masyarakat mengenai BUMDes yang baru berdiri

\section{Deskripsi Strategi pengembangan BUMDes di desa Oesena}

Strategi merupakan suatu tolak ukur keberhasilan dari suatu perusahaan atau lembaga. Sehingga strategi dapat didefinisikan sebagai suatu arah tindakan atau rencana, termasuk di dalamnya sumber daya tertentu yang dibutuhkan untuk mencapai tujuan BUMDes. Setiap organisasi atau perusahaan memiliki tujuan, tetapi karena sifat dinamis dari lingkungan organisai, strategi atau rencana menyeluruh dibutuhkan untuk memperinci bagaimana tujuan organisasi dapat dicapai dalam lingkungan yang tidak pasti.

\section{PEMBAHASAN \\ Potensi-Potensi ekonomi di desa Oesena}

Potensi adalah segenap sumber daya alam dari sumber daya manusia, yang dimiliki desa sebagai modal dasar yang perlu dikelola dan dikembangkan bagi kelangsungan dan perkembangan desa. Potensi yang ada di desa Oesena ini juga diharapkan dapat mendukung kemajuan desa, baik dari sumber daya alam, potensi sumber daya manusia, potensi kelembagaan, maupun potensi prasarana dan sarana. Desa Oesena memiliki asset-aset desa seperti lahan kosong yang belum termanfaatkan sebagai sumber penghasilan desa jika dikelola dengan baik, potensi air permukaan yang cukup besar sebagai sumber pengairan, berdasarkan potensi-potensi diatas maka hal ini seharusnya dijadikan dasar diadakan penyuluhan mengenai BUMDes di masyarakat. Namun dengan adanya potensi tersebut masyarakat masih mengelolanya sendiri-sendiri dalam memenuhi kebutuhannya. Yang disebut sebagai potensi masyarakat bukan hanya soal sumber ekonomi tetapi juga apa yang selama ini menjadi keluhan masyarakat, hal tersebutlah yang menjadi berdirinya BUMDes. Mengingat BUMDes yang masih baru sehingga peran dan inisitif masyarakat masih kurang dalam mendukung dan mengapresiasi BUMDes saat ini. Namun saat ini BUMDes dapat berjalan dengan baik sesuai dengan potensi-potensi dan kebutuhan dalam unit-unit usaha yang telah disiapkan. Pengelola Badan Usaha Milik Desa juga berupaya menyakinkan masyarakat desa untuk mengembangkan unit-unit usaha tersebut dengan menitip barang jualan atau barang usaha masyarakat di Badan Usaha Milik Desa seperti minyak kelapa murni dan sepatu tenunan asli dari desa Oesena.

Analisis Kekuatan, Kelemahan, Peluang, dan Ancaman dalam pengembangan BUMDes. Berdasarkan deskripsi analisis SWOT B UMDes Harapan Oesena di desa Oesena maka peneliti merumuskan formulasi strategi dalam pengunaan matriks SWOT. Analisis SWOT membandingkan antara faktor eksternal Peluang (Opportunity) dan Ancaman (Threats) dengan 
faktor internal Kekuatan (Strenght) dan Kelemahan (Weakness). Unsur - unsur SWOT Kekuatan (Strenght), Kelemahan (Weakness), Peluang (Opportunity), Ancaman (Threats).

Faktor eksternal dan internal, menurut (irham fahmi,2013) untuk menganalisis secara lebih dalam tentang SWOT, maka perlu dilihat faktor eksternal dan internal sebagai bagian penting dalam analisis SWOT, yaitu: Faktor eksternal Faktor eksternal ini mempengaruhi terbentuknya Opportunities and Threats $(\mathrm{O}$ dan T). Faktor ini menyangkut dengan kondisikondisi yang terjadi di luar perusahaan yang mempengaruhi dalam pembuatan keputusan perusahaan dan juga mencakup faktor lingkungan industri dan lingkungan bisnis makro, ekonomi, politik, hukum, teknologi, kependudukan, dan sosial budaya.

Faktor internal ini mempengaruhi terbentuknya Strenghts and Weaknesses (S dan W), yaitu menyangkut dengan kondisi yang terjadi dalam perusahaan dan turut mempengaruhi terbentuknya pembuatan keputusan (decision making) perusahaan. Faktor internal ini meliputi semua macam manajemen fungsional : pemasaran, keuangan, operasi, sumberdaya manusia, penelitian dan pengembangan, sistem informasi manajemen dan budaya perusahaan (corporate culture). Menurut formulasi strategi analisis SWOT ini peneliti harapkan agar perangkat desa, pengelola BUMDes dapat memperhatikan strategi dalam setiap analisis SWOT yang dikemukkan oleh peneliti agar perangkat desa, pengelola BUMDes dan masyarakat dapat memanimalisir setiap kekurangan yang ada dalam pengembangan BUMDes tersebut.

\section{SIMPULAN}

1. Potensi-potensi ekonomi yang ada di desa Oesena secara keseluruhan yang menjadi keunggulan potensi ekonomi desa ialah potensi sumber daya alam dan potensi tenun ikat, sedangkan potensi sumber daya manusia, potensi kelembagaan, dan potensi prasarana dan sarana masih membutuhkan dukungan, kerja sama dan tidak lanjut dalam pengembangan BUMDes.

2. Tingkat kemajuan pengelolaan BUMDes Secara keseluruhan tingkat kemajuan pengelolaan BUMDes masih rendah dan belum mengalami peningkatan yang signifikan. BUMDes yang dikembangkan di desa Oesena Kabupaten Amarasi dinilai dapat dimanfaatkan sebagai roda perputaran uang serta dapat mengatasi masalah dan dapat dimanfaatkan dalam potensi ekonomi di desa namun saat ini BUMDes belum efektif dan berkembang dengan baik.

3. Kekuatan, kelemahan, peluang dan ancaman dalam pengembangan BUMDes Analisis kekuatan, kelemahan, peluang dan ancaman (SWOT) dalam pengembangan BUMDes di desa Oesena yaitu : kekuatan BUMDes dapat dilihat dari potensi sumber daya alam, potensi tenun ikat, serta SDM dalam kaitannya dengan ketrampilan (skill) yang dimiliki dapat memenuhi kebutuhan masyarakat, kelemahan BUMDes dapat dilihat dari potensi sumber daya manusia yang memilik tingkat pendidikan yang rendah dan belum maksimal dalam bekerja, potensi kelembagaan dan potensi prasarana dan sarana yang belum diperhatikan oleh perangkat desa dan pengelola desa dengan baik dan belum efektif, peluang BUMDes dapat dilihat dari peran BUMDes dalam pemberian lowongan pekerjaan sehingga masyarakat dapat bekerja dan mendapatkan pendapatan tetap jikalau masyarakat dapat bekerja sama dengan baik dengan pihak perangkat desa dan pengelola BUMDes.

4. Strategi pengembangan BUMDes Strategi yang dibuat oleh pengelola BUMDes terkait dengan pengembangan BUMDes Harapan Oesena masih relatif rendah, karena pengelola BUMDes belum merencanakan strategi yang semestinya.

\section{DAFTAR PUSTAKA}

RPJM, (2017-2022) "Rencana Pembangunan Jangka Menengah Desa". Kupang. Rangkuti, Freddy (2001). "Analisis SWOT Teknik Membedah Kasus Bisnis"Reorientasi, Konsep, Perencenaan, Strategis Untuk Menghadapi Adab 21, Penerbit PT Gramedia Pustaka Utama, Jl. Palmerah Selatan 24-26, Lt. 6 Jakarta 10270, 2001.

Budiono, Puguh (2015). "Implementasi Kebijakan Badan Usaha Milik Desa (BUMDes) Di Bojonegoro (Studi di Desa Ngringinrejo Kecamatan Kalitidu Dan Desa Kedungprimpen Kecamatan Kanor)". Jurnal Politik Muda, Vol. 4 No. 1, Januari-Maret 2015, 116-125.

Chintary, V. Q., \& Lestari, A. W. (2016). PERAN PEMERINTAH DESA DALAM 
PENGEMBANGAN BADAN USAHA MILIK DESA (BUMDes). JISIP: Jurnal Ilmu Sosial Dan Ilmu Politik.

Kurniasih, D., Setyoko, P. I., Imron, M., \& Wijaya, S. S. (2019). The role of stakeholders in the Accountability of Village Enterprise Management: A Public Governance Approach. IOP Conference Series: Earth and Environmental Science. https://doi.org/10.1088/1755-

1315/255/1/012056

Kusuma, T. (2018). PEMBENTUKAN DAN PENGELOLAAN BUMDES (BADAN USAHA MILIK DESA) KARYA MANDIRI SEJATI (Studi. In Journal of Chemical Information and Modeling.

Miles, M. B., \& Huberman, M. A. (2012). Analisis Data Kualitatif: Buku Sumber Tentang Metode-Metode Baru. In Universitas Indonesia_UI Press.

Siagian, A. O. (2019). Pengaruh Daya Tarik Iklan Dan Penempatan Produk Terhadap Kesadaran Merek Grab di Acara Indonesian Idol 2018. Jurnal Pemasaran Kompetitif.

https://doi.org/10.32493/jpkpk.v3i1.3621

Siagian, A. O. (2020). PENGARUH PENDAPATAN ASLI DAERAH (PAD), DAN DANA TRANSFER TERHADAP PENGALOKASIAN ANGGARAN BELANJA MODAL (Studi pada Pemerintah Provinsi D.I. Yogyakarta). Jurnal Bisnis Terapan. https://doi.org/10.24123/jbt.v4i2.2848

Siagian, A. O., Martiwi, R., \& Indra, N. (2020). Kemajuan Pemasaran Produk Dalam Memanfaatkan Media Sosial Di Era Digital. Jurnal Pemasaran Kompetitif. https://doi.org/10.32493/jpkpk.v3i3.4497

Siagian, A. O., \& Prasetyo, T. F. (2020). Strategi

Pengembangan Kompetisi Usaha Kecil

Menengah di Kabupaten Jombang. Jurnal Akrab Juara.

Wijaya, David ( 2018 ). "Badan Usaha Milik Desa (BUMDes)". Penerbit Gava Media, Solusi Membangun Generasi Cerdas, Yogyakarta.

Zulkarnaen, Reza M (2016). "Pengembangan Potensi Ekonomi Desa Melalui Badan Usaha Milik Desa (BUMDes) Pondok Salam, Kabupaten Purwakerto". Jurnal Aplikasi Ipteks untuk Masyarakat ISSN 1410 - 5675 Vol. 5, No. 1, Mei 2016: 1 - 4 (2016).
Undang-Undang Nomor 32 Tahun 2004 tentang Pemerintahan Daerah. Undang- Undang Nomor 6 Tahun 2014 tentang Desa 